\title{
Investigating the Strategies for Supply Chain Agility and Competitiveness
}

\author{
Samudi Perera*, Claudine Soosay and Sukhbir Sandhu
}

\begin{abstract}
Manuscript type: Research paper

Research aims: This study explores the strategies that enable firms to establish supply chain agility and competitiveness in Australian manufacturing firms.

Design/Methodology/Approach: Using a case study approach, interviews are conducted with eight Australian manufacturing firms. Underpinned by the dynamic capability perspective, data are then thematically analysed to derive the findings.

Research findings: Agility strategies are based on collaborative efforts, requiring information sharing among firms in the supply chain and diversifying core competencies in a strategic manner to remain competitive.

Theoretical contribution/Originality: This study shows how dynamic capabilities foster competitive advantage. It identifies both the strategic and operational agility which enable firms to respond to market changes and to remain competitive.

Practitioner/Policy implication: The manufacturing industry in Australia is undergoing a transition where Australian manufacturers
\end{abstract}

\footnotetext{
* Corresponding author: Samudi Perera is an Early Career Researcher having completed her $\mathrm{PhD}$ in 2017 from the School of Management, University of South Australia Business School, Adelaide, SA 5001. Email: samudi.perera@mymail.unisa.edu.au

Claudine Soosay is an Associate Professor of Operations and Supply Chain Management at the School of Management, University of South Australia Business School, Adelaide, SA 5001. Email: Claudine.Soosay@unisa.edu.au

Sukhbir Sandhu is a Senior Lecturer of Sustainability and Strategy at the School of Management, University of South Australia Business School, Adelaide, SA 5001. Email: sukhbir.sandhu@unisa.edu.au
} 
need to transform and be more agile by leveraging their competencies and supply chains collectively.

Research limitation/implications: The results are based on a crosssectional study of firms identified from the Australian manufacturing industry.

Keywords: Agility, Australian Manufacturing, Operations, Strategy, Supply Chains

JEL Classification: I3, M14

\section{Introduction}

The manufacturing industry plays a significant role in the Australian economy, contributing 6 per cent of the nation's gross domestic product, and accounting for 32.2 per cent of total exports (Office of the Chief Economist, 2016). According to the Australian and New Zealand Standard Industrial Classification (ANZSIC), the manufacturing industry includes diverse sectors, ranging from low value-added commodity products to high precision products such as automotive, medical devices and pharmaceuticals (Australian Bureau of Statistics, 2016). The manufacturing industry is a significant component in the value chains of other Australian industries such as services, transport, infrastructure and agribusiness (Commonwealth Scientific and Industrial Research Organisation, 2011; 2012). Australia's manufacturing competitiveness index ranking moved from 21 in 2017 to 19 in 2018 (International Institute for Management Development, 2018), which indicates industry progression. However, after two years of expansion, the industry reported its lowest performance in the manufacturing index in December 2018 (The Australian Industry Group, 2018). The low performance pointed to the declining activities of the industry (Scutt, 2019), particularly in the manufacturing of chemical and metal products as well as machinery and equipment (Manufacturers' Monthly, 2019). This declining trend is the result of high input costs such as energy and labour (Manufacturers' Monthly, 2019), fierce competition and disruptive new technologies experienced by the industry (Lannin, 2018). For Australian manufacturing to remain competitive, businesses should transform to meet these changing needs (Lannin, 2018) and develop a more agile approach.

Research (Carvalho, Azevedo, \& Cruz-Machado, 2012; Chen, 2018; Wu, Tseng, Chiu, \& Lim, 2017; Yusuf et al., 2014) has highlighted the 
significance of agile supply chains for competitiveness. The capability of a firm to be responsive and versatile in adjusting its supply chain to rapid market changes is important. This is termed as supply chain agility. Even though there are earlier studies (e.g., Christopher, 2000; van Hoek, Harrison, \& Christopher, 2001; Yusuf et al., 2014) highlighting the characteristics of supply chain agility, the concept is still evolving, as noted by Aslam, Blome, Roscoe and Azhar (2018) and Gligor, Holcomb and Stank (2013).

This study investigates the strategies that successful manufacturing firms adopt to instil supply chain agility in their organisations and supply chain operations. It answers the research question, 'What strategies are evident in manufacturing firms for ensuring supply chain agility, and how do they facilitate a competitive advantage?' Based on interviews conducted with managers in eight Australian manufacturing firms, our findings highlight the need for Australian manufacturers to embrace market challenges, detect changes in supply and demand, reconfigure resources, and exploit knowledge for their own advantage.

The rest of this paper is structured as follows. Section 2 and Section 3 discuss literature on the supply chain agility and theoretical background of this study respectively. Section 4 describes the methodology approach, whilst Section 5 provides the analysis of the study's results. Section 6 discusses the empirical results and Section 7 concludes by looking at the limitations and implications.

\section{Literature Review}

\subsection{The Importance of Agility}

Literature that focusses on manufacturing and supply chain management has highlighted that the concept of agility is common in today's competitive market because it is relevant to the achievement of competitiveness in current turbulent market conditions (Tse, Zhang, Akhtar, \& MacBryde, 2016; Wu et al., 2017). The concept of agility first originated from the manufacturing system, and it was later expanded from the organisational level to the supply chain level. The first reference made to the term agility appeared in 1991 in the report '21st Century Manufacturing Enterprise Strategy' (Castro, Putnik, \& Shah, 2012). The report described agility as a solution that US manufacturers can offer to the next generation of competition. Agility enables a firm to respond to the changing demands by fulfilling them and producing highly 
customised products (Nagel, 1992). Agile manufacturing expands the focus of the industry to go beyond flexibility, as seen in the mix and volume of production (Christopher, 2000; Rimienè, 2011). Agility has become a customer-oriented management approach which demonstrates both reactive and proactive measures in meeting customer needs. It occurs with firms adjusting their processes, products or services, and the volume of production (Castro et al., 2012). Organisations that practise agile manufacturing can achieve multiple objectives, such as cost reduction, quality enhancement, flexibility, shorter delivery times, better services and a leading-edge technological production (Eshlaghy, Mashayekhi, Rajabzadeh, \& Razavian, 2010; Vázquez-Bustelo, Avella, \& Fernández, 2007). Consequently, agile manufacturing strengthens the organisations' operational, market and financial performance (VázquezBustelo et al., 2007).

Realising the benefits of agile manufacturing, the concept was later expanded to encompass the entire business (Christopher, 2000). The concept of agility has been defined by Dove (1994) as the ability to adapt to environmental changes. He espoused that agility is a change proficiency of organisations. Clearly, an agile organisation incorporates this proficiency into all its processes to achieve responsiveness in strategies, technologies, personnel, business processes and facilities (Tseng \& Lin, 2011). Agility improves responsiveness by combining flexible organisational structures and human skills (Christopher, 2011). The level of agility which an organisation can attain is limited by the ability of the other parties whom the firm engages with (Kumar \& Ramakrishna, 2011; Swafford, Ghosh, \& Murthy, 2006), and the type of environment in which the firm operates ( $\mathrm{Wu}$ et al., 2017). The parties that a firm engages with can comprise the supply chain partners which enable the firm to be agile in its supply chain (van Hoek et al., 2001). The scope of agility, therefore, should be extended beyond the firm to also consider the ability of the supply chain partners in creating an agile supply chain as a whole (Braunscheidel \& Suresh, 2009; Lee, 2004).

\subsection{Agility in Supply Chains}

The concept of agile supply chains was introduced in 1996 (Dove, 1996) to mean all the parties are integrated and coordinated, enabling the firm to identify and to respond to market changes quickly and accurately (Christopher, 2000). With the use of information technology, firms have access to demand information quickly and can adjust production 
plans and inventories while coordinating with suppliers to procure the required materials for timely production (Christopher, 2000; van Hoek et al., 2001).

The concept of agile supply chains has appeared in the literature via different terminologies such as 'supply chain agility', 'agility in supply chains' and 'agile supply chains'. These terminologies have slight variations depending on the level of the supply chain they represent. For example, the term 'agile supply chains' reflects the composition of a supply chain to enable agility whereas 'supply chain agility' and 'agility in supply chains' refer to the capability of firms in the supply chain to be agile, and to make the supply chain partner-firms agile in turn. Following the studies of Blome, Schoenherr and Rexhausen (2013), Braunscheidel and Suresh (2009), Gligor, Esmark and Holcomb (2015) and Yang (2014), this study adopts the term and concept of 'supply chain agility' as the ability of a firm to adjust its supply chain to rapidly respond to market changes.

The most frequently cited elements noted in the literature that examines agility are: customer sensitivity, network integration, process integration and leveraging the impact of people and information (Christopher, 2000; van Hoek et al., 2001; Yusuf et al., 2014). Customer sensitivity and network integration are about detecting market changes (Christopher, 2000; van Hoek et al., 2001). Firms detect market changes in real time, and they become sensitive to such changes (Chen, 2018; Yang, 2014). Information integration enabled through ICT furnishes real time access to information (Kim \& Chai, 2017). The shared information is demand-related and operations-related, such as inventory, planning and procurement, all of which enable knowledge exploitation. Information integration increases visibility among the supply chain partners; it enables joint planning between firms and the supply chain partners to streamline processes, to reconfigure resources within the chain, and to respond to changes accordingly (Braunscheidel \& Suresh, 2009; Dubey et al., 2018).

Research has focused on the physical elements that foster agility (e.g., Braunscheidel \& Suresh 2009; Christopher, 2000; van Hoek et al., 2001; Yang, 2014; Yusuf et al., 2014) but only a few studies have examined the underlying aspects which enable these elements (e.g., Aslam, et al., 2018; Gligor et al., 2013). Gligor et al. (2013) identified agility as being developed through combining the cognitive and physical capabilities of the firms. Cognitive capabilities are the alertness (the ability to quickly detect the changes in markets), accessibility (the ability 
to access relevant data) and decisiveness (the ability to make decisions) which enable firms to process information, and to determine the actions needed. Swiftness (the ability to implement those decisions quickly) and flexibility (the ability to adjust operations and procedures along with the changing needs) are the physical components which permit firms to implement actions (Gligor et al., 2013). Firms' market sensing ability can increase their supply chain agility (Aslam, et al., 2018).

\subsection{Characteristics of Agility in Supply Chains}

Supply chain agility focusses on increasing firms' responsiveness towards market changes (Qrunfleh \& Tarafdar, 2013; Tse et al., 2016; Wieland, 2013). This takes place when firms identify and anticipate market changes and then react ahead of their competitors. However, the critique is that agility is mainly about responsiveness and a measure of reaction time (Swafford, Ghosh, \& Murthy, 2008). Several published studies (Carvalho et al., 2012; Lee, 2004; Van Oosterhout, Waarts, \& van Hillegersberg, 2006; Wu et al., 2017) describe agile supply chains as being responsive to unpredictable changes in market conditions. Other studies (Fayezi, Zutshi, \& O'Loughlin 2015; Li, Chung, Goldsby, \& Holsapple, 2008) stress the importance of proactive actions in exploring opportunities, instead of just being reactive to market changes.

Even though addressing market changes is the main concern of firms and their supply chain, there have been some inconsistencies in the definition of the type of market changes involving agility. To date, the discussion of supply chain agility has largely concentrated on demand variations only (e.g., Blome et al., 2013; Braunscheidel \& Suresh, 2009; Charles, Lauras, \& Wassenhove, 2010; Khan \& Pillania, 2008). Realistically, agility enables firms to overcome both the demand and supply variations. This was verified by $\mathrm{Li}$ et al. (2008) and $\mathrm{Li}$, Goldsby and Holsapple (2009) who identified three types of market variations for supply chain agility that can cause demand and supply changes. These occur due to changes in business environments, such as technology, political, social and demographic related factors; changes in available demand and supply, and sudden one-off incidents. Based on these factors, it can be deduced that supply chain agility embraces opportunities and challenges arising from various market changes.

The important features of supply chain agility in responding to changes are the response speed and the ability to develop appropriate 
solutions to address the changes (Swafford et al., 2008). Hence, supply chain agility is about responding in a flexible and timely manner. Supply chains minimise the risk of losses, thereby making firms more competitive (Swafford et al., 2008). Importantly, supply chain agility reflects features of a dynamic capability which involves various processes that can detect changes and reconfigure resources (Carvalho et al., 2012).

Based on the different definitions of agility and supply chain agility, it can be established that agility is a requirement for addressing dynamic markets. It is particularly relevant for the manufacturing industry. Firms develop agile capabilities while working with other partners in the supply chain in order to form an agile supply chain. This notion of agility has been investigated in previous studies (e.g., Braunscheidel \& Suresh 2009; Christopher, 2000; Gligor et al., 2013; Swafford et al., 2008) and termed as supply chain agility. Because of the firm's ability to address market changes by manipulating resources, it would appear that supply chain agility is also the firm's capability to be dynamic and to influence other partner firms into altering their operations. The dynamic nature of the supply chain agility is becoming more apparent today; hence this study is relevant and contributes to the field by examining Australian manufacturing firms. It appears that Australian manufacturers are currently embracing various efforts, initiatives and programmes in being competitive and in coping with the changes which are affecting both the industry and the market.

\section{Theoretical Underpinning}

The dynamic capability perspective explains how firms achieve competitive advantage (Helfat \& Peteraf, 2009). Dynamic capability is relevant for supply chain issues in the changing market (Beske, 2012; Defee \& Fugate, 2010). This theory explains how firms attain competitive advantage by responding to environmental changes (Teece, 2007). Thus, dynamic capability serves as the underpinning theory for the current study.

\subsection{Dynamic Capability Perspective}

Dynamic capability refers to the firm's ability to accommodate the changing environmental conditions, thereby developing a competitive advantage by finding the means to create, maintain and renew its competitive bases (Easterby-Smith, Lyles, \& Peteraf, 2009). The concept of dynamic capability originated from Teece, Pisano and Shuen (1997) 
who established that a firm's competitive advantage is fostered through firm-specific resources or competencies in situations where technology and market forces are rapidly changing (Katkalo, Pitelis, \& Teece, 2010; Wang \& Ahmed, 2007).

A firm's dynamic capability is grouped into three categories: managerial and organisational processes, position, and paths (Teece et al., 1997). Managerial and organisational processes refer to the way things are done in the firm, such as routines or practices. These processes have three roles: 1) coordinate and integrate internal and external activities, 2) organisational and individual level of learning and identifying the need for changes, and 3) accomplish changes to organisational structures and assets (Teece et al., 1997). Position refers to the specific assets which the firm possesses. The firm's assets comprise technology and other supporting elements that enable producing and delivering new products and services. These supporting elements include the firm's financial position, reputation, organisational structure, institutional setting and marketing conditions. Paths refer to the strategic alternatives which are available to the firm. A firm's future position is dependent on its current position and the opportunities available. Furthermore, previous paths taken by the firm are also a determining factor for the firm's present position; these also affect the firm's future. Today's world has become digitally based, hence technological opportunities can also influence industrial activities. This implies that firms need to adopt strategic alternatives for their operations to adapt to changing times. Such a process involves assessing the firm's capacity to reconfigure and to transform (Teece et al., 1997). Learning mechanisms can alter the path which firms undertake (Eisenhardt \& Martin, 2000). Accordingly, a firm's competitive advantage is vested in its managerial and organisational processes; these are influenced by the firm's asset position and the paths it undertakes. This implies that the dynamic capabilities lie within the managerial and organisational processes of coordination, integration, learning and reconfiguration (Teece et al., 1997). These capabilities modify the organisation's position to become more competitive while leading it towards new positions and new paths. Accordingly, Teece et al. (1997) assumed that organisational and managerial processes are the core elements of a firm's dynamic capability.

Teece (2007) subsequently identified particular types of dynamic capabilities that enable firms to evolve according to market changes. These include sensing (opportunity identification), seizing (investment in opportunities), and managing transformation (resource reconfiguration). 
The sensing and seizing capabilities drive the firms towards new positions and paths, which thereby improve the firm's performance and enhance its competitive advantage. Additionally, the capability of resource reconfiguration modifies the assets of the firm, thereby giving rise to the firm's competitive advantage while also developing new positions and paths for the firm.

Another perspective of a firm's dynamic capability is its composition of adaptive, absorptive and innovative capabilities (Wang \& Ahmed, 2007). Adaptive capability refers to the firm's ability to adapt to the changing environment by flexibly aligning its internal organisational resources with external market requirements. Absorptive capability refers to the firm's attainment of external knowledge and transforming it for internal use. Innovative capability refers to the firm's ability to develop new products or markets by linking its resources and capabilities (Wang \& Ahmed, 2007). The combination of the absorptive and innovative capabilities form the firm's sensing and seizing abilities while its adaptive capability serves as the firm's ability to reconfigure resources. This view is in line with the dynamic capabilities of sensing, seizing and reconfiguration.

Dynamic capabilities rest on the assumption that competencies provide a competitive advantage and rents, only if they are based on difficult-to-imitate routines, skills and assets (Teece et al., 1997). Competencies are organisational resources which result from repetitive or quasi-repetitive activities (Katkalo et al., 2010). In fact, organisational or managerial processes and routines derive competencies which can alter resources to address market changes. Imitation is the action of replication by competitors. Replication tries to transfer or deploy competencies from one setting to another. The dynamic capability view thus holds that difficult-to-replicate competencies increase a firm's competitive advantage. The replication of competencies or capabilities can be quite difficult when the processes are routine-based, especially if the tacit component is high. These routines develop the firm's dynamic capabilities, and so change the way the firm operates (Helfat \& Winter, 2011).

Difficult to replicate, routine-based dynamic capabilities imply that firms must build them internally (Katkalo et al., 2010), and the recurrent use will improve the capabilities of the firms over time (Helfat \& Winter, 2011). In dynamic market conditions, firms frequently utilise dynamic capabilities to alter assets, skills and competencies in order to develop and maintain a distinctive resource base within the company, aligning it with market changes (Teece, 2007). In this regard, 
firms need to continuously improve the capabilities of changing their distinctive resources. Notably, the dynamic capabilities of firms will continually improve the firms' existing capabilities, otherwise, leading to new capabilities. Therefore, the dynamic capability view explains how firms sustain their capabilities-based competitive advantage, under environmental changes (Helfat \& Peteraf, 2009).

With the shift in market competition and moving from a firm level to the supply chain level, researchers have applied this theory to explain how firms establish competitive advantage in the supply chain (Defee \& Fugate, 2010). This refers to the inter- and intra-organisational competencies which create new static capabilities or modify firms' existing capabilities across supply chain partners (Defee \& Fugate, 2010).

\subsection{Dynamic Capabilities for Agility in Supply Chains}

Supply chain agility is a firm's ability to respond to market changes by adjusting operations and coordinating with supply chain partners. Researchers (Aslam et al., 2018; Blome et al., 2013; Chiang, KocabasogluHillmer, \& Suresh, 2012; Gligor \& Holcomb, 2012b) have acknowledged this as a dynamic capability. In supply chain agility, information sharing is a vital component (Dubey et al., 2018; Kim \& Chai, 2017). Through shared information, firms are able to capture the market changes in a timely manner. Firms demonstrate the 'sensing' capability to search out opportunities and threats by detecting the changes in demand, supply as well as other environmental factors. This awareness of market changes, especially with regards to the market and customer, enables the firms to embrace market opportunities and challenges through integrating processes.

Additionally, integration of functional areas within the firm and with supply chain partners are key attributes of agility (Braunscheidel \& Suresh, 2009). The process integration can be accomplished through cooperation and coordination with supply chain partners (Chen, 2018; Christopher, 2000; Yusuf et al., 2014). Learning also plays a significant role in integration since past experience is influential in deciding how to integrate processes with evolving opportunities and threats (Braunscheidel \& Suresh, 2009). In doing so, firms can embrace market changes by working together with supply chain partners to develop new solutions through knowledge exploitation (Chen, 2018; Rasli \& Mohd, 2008).

Another characteristic is the reconfiguration of resources where firms modify supply chain structures, resources and adapt to changes 
rapidly, in a timely manner, both upstream and downstream (Carvalho et al., 2012; Swafford et al., 2008). These adjustments include supplier quantities, delivery times, reduced production schedules and batch sizes, and product development (Carvalho et al., 2012; Swafford et al., 2008). Reconfiguration indicates the firms' transforming behaviour and adapting capability.

Therefore, supply chain agility comprises the managerial and organisational processes supportive of dynamic capabilities such as, coordination and integration, learning and reconfiguration; and also demonstrates the sensing, seizing and reconfiguring abilities. These attributes reinforce supply chain agility as a dynamic capability, and they appropriately explain how agility influences the competitive advantage of supply chains.

\section{Methodology}

This is an exploratory qualitative study that uses the case study method. According to Yin (2018), three to six cases are considered adequate for an in-depth case study analysis without leading to data overload. Primary data are gathered from interviews and supplemented with publicly available documents, annual reports and information available on websites.

Semi-structured face-to-face interviews as well as telephone interviews are conducted with eight managers who held senior appointments in high-performing manufacturing firms in Australia. These managers are contacted through purposive sampling based on a database of manufacturers. Purposive sampling allows the researchers to select the most suitable respondents to answer the research questions (Bryman, 2008). As senior managers, they are deemed knowledgeable about the supply chain operations and issues related to their company's industry. The interviewees' profile is provided in the Appendix.

Interviewing is the most common method for data collection in qualitative research (Bluhm, Harman, Lee, \& Mitchell, 2011). This study adopts a semi-structured interview protocol because it offers the opportunity to further probe the issues under investigation. The face-to-face interviews took place at the premises of the respective organisations. Each interview lasted approximately an hour and are audio recorded with the consent of the interviewee.

In addition to the interviews, data are also obtained from the corporate websites and publicly available sources such as company 
brochures. Collecting data from multiple sources helped in triangulation and improved the accuracy of the data (Creswell, 2014). Data are analysed using the thematic analysis approach (Gioia, Corley, \& Hamilton, 2012).

Analysis of data involved three steps: 1) coding of raw data into first order codes and then labelling these with appropriate names; 2 ) consolidating these codes into second order conceptual categories according to their similarities and differences; and 3) consolidating the conceptual categories into third order theoretical dimensions. In the first step, codes are identified based on the data. Coding is done for each case and new codes are developed as new meaningful segments emerged. These codes represent various activities that the firms took to maintain their supply chain agility. The codes are labelled to best represent the data. For example, "adjust operations in line with market changes", "adjust operations in line with future expected changes", "adjust operations to supply changes", "receive information about supply changes", "receive information about customer demand", "business process integration to update supply and demand information", etc. The data obtained from the secondary sources are also similarly coded. In the second step, similar codes are grouped into second order conceptual categories. For example, the first order codes "adjust operations in line with market changes", "adjust operations in line with future expected changes" and, "adjust operations to supply changes" were combined into the second order category labelled "adjust processes to respond to changes". The second order conceptual categories are compared with literature to arrive at the third order theoretical dimensions (e.g., the second order category, "adjust processes to respond to changes" was combined with the category, "strategic changes" to develop the theoretical dimension, "reconfiguring resources and strategies").

\section{Findings}

Due to the need for commercial confidentiality, the companies are described anonymously. The eight Australian companies are referred to as Firm A to Firm H.

\subsection{The Companies and Their Operations}

Firm A is an Australian industrial firm which offers building products for residential and commercial constructions. These products include plasterboards, fibre cement, bricks and pavers, concrete panels, walling 
solutions, roof tiles and glass. The firm was founded in 1885 but it entered into building products in 1942. Currently, it employs 4,282 employees, has an annual revenue of AUD2.6 billion and operates in China, Thailand and Malaysia.

Firm B is one of Australia's largest meat processing companies, with an annual revenue in excess of AUD1.3 billion. The company began its operations in South Australia in 1988. Presently, it has four plants operating - two in South Australia and one each in New South Wales and Queensland. Firm B employs approximately 2,000 people. It processes 120,000 lambs and sheep and 5,000 cattle per week. The majority of products are exported to 80 countries.

Firm $C$ is a manufacturer for plastic moulding and plastic products. It was established in 1989 as a privately-owned business. The manufacturing plant is in South Australia, with an annual revenue of over AUD11 million, employing about 60 staff. The company mainly supplies its products to automobile manufacturers within Australia. Due to the downturn of the automotive industry, the company is now planning to diversify into other industries.

Firm D operates in the printing support services. It is a subsidiary of a large global technology provider in the printing industry. The European-based parent company develops all the necessary technologies and complimentary components for commercial and packaging printing needs. The Australian strategic partnership offers printing products, services and consumables to the Australian market, including ink, paper and printing plates. The company operates with a network across all the six states of Australia.

Firm $\mathrm{E}$ is a contract food manufacturer of ultra-high temperature (UHT) liquid cheese, and a variety of dairy and tomato-based sauces. It started as a small business in 1991, serving three Mexican restaurants. It has grown to become a leading food manufacturer that serves industrial manufacturers, quick-service restaurants, food services, contract packing, as well as export and retail in Australia. The firm currently employs around 20 staff. The company has acquired the state-of-the-art food processing and packaging technologies. It also offers business solutions to customers by providing innovative product ideas through recipe development.

Firm $\mathrm{F}$ is a packaging manufacturer. It started operations in the 1920s with a cardboard manufacturing plant in Melbourne. After acquiring several other packaging companies over time, Firm $\mathrm{F}$ has grown to become one of the main packaging solution providers in Australia. At 
present, the company has three plants operating in Melbourne, Sydney and Auckland respectively. It currently employs around 600 staff. The product range it offers includes folding cartons, self-adhesives, paper cups, flexible materials such as films and foils, packing systems and digital solutions. The company serves a wide variety of markets including pharmaceuticals, health care, food and beverage, confectioneries, wines, cosmetics, technological and fast-moving consumer goods.

Firm $G$ operates in the measurement and scientific equipment industry in Australia. It is headquartered in North America. The firm offers innovative technologies in analytical instruments, laboratory products and services, and specialty diagnosis and life sciences solutions for customers in research, as well as clinical and applied markets. It also serves a wide range of industries such as oil and gas, mining, energy, aerospace and defence, steel, aluminium, plastics, rubber, and nonwoven manufacturers, construction, transportation and pharmaceuticals, to name a few.

Firm $\mathrm{H}$ is a motor vehicle manufacturer in Australia. It is a fullyowned subsidiary of a North American transportation company. It manufactures trains, rail transportation systems, controlling and signalling systems, and light rail vehicles. It operates in 22 locations in Australia with 1,100 employees. The firm has built strong long-term partnerships with 1,500 Australian suppliers.

\subsection{Strategies for Supply Chain Agility}

Upon a thorough analysis of the data, the responses drawn from the managers regarding the strategies used for supply chain agility are clustered into four main themes: 1) embracing market challenges, 2) detecting changes in supply and demand, 3) reconfiguring resources and strategies, and 4) exploiting knowledge.

\subsubsection{Embracing Market Challenges}

Firm $\mathrm{A}$ is a building product manufacturer. It captures market information and trends, and responds to these changes accordingly. Home units have gained popularity over recent years and this has led to some changes desired for the materials needed in the building industry. The firm has addressed this challenge by introducing new designs and speeding up or slowing down the operations, as a reactive strategy towards meeting market demand fluctuations. This flexibility 
has enabled Firm A to market and sell the building materials more effectively:

While detached housing will remain a core part of our market, we are increasing our exposure to multi-residential through products and systems in our portfolio and through the recent acquisition of XXX Products Group. (Annual report, Firm A)

Firm B is a meat producer. It faces heavy competition, not only domestically, but also internationally, from imported meats offered by China. The market structure for the lamb industry had changed significantly over the past two decades; shifting from wool production to meat production. Establishing their produce as a niche premium product, Firm B currently faces supply shortage and also competition from China and New Zealand. Firm B has identified the issue and noted that to keep abreast with market challenges, it requires a global strategy, by investing and acquiring two large distribution businesses within Australia and in the US (which represents around 75 per cent of their business portfolio). Doing so would allow Firm B to identify the market changes directly, through their customers in those markets. Their current strategy is to collaborate with industry associations so as to develop quality products which are targeted at the high-end sector. Firm $B$ believes that adopting a value chain approach will enable the firm to become a preferred supplier for premium meat products:

We identify market changes through direct contact with our customers in those markets. In that sense, we are linked to the Australian market and to the American market which is about 60-75 per cent of our business. So, we have very good contacts there ...W We've got to turn around from supply chain to a value chain and focus on our meat consumers and customers. That's how we keep up with market information by making sure that we are a preferred supplier for premium products. (Supply Chain Coordinator, Firm B)

Firm $\mathrm{C}$ is an industrial product manufacturer. It relies on its immediate customers for market needs since forecasting the demand for such products can be challenging. While Firm C carries out a make to order strategy, it also maintains competitiveness by building on existing customer relationships as well as developing new product lines to establish its superior quality. Although the current clientele helps Firm $C$ to sustain its business, there are other avenues to seek new 
customers from different markets and diversify its moulding and plastic production to other sectors too:

We have been developing a strategy to diversify our products and going to different market sectors. We are currently in the process of creating new markets for ourselves. (Purchasing Manager, Firm C)

Firm D is a manufacturer for the print media industry. It has adopted various mechanisms to identify current market challenges and new opportunities. The sales and product management team of Firm $\mathrm{D}$ actively participates in industry forums where the team can obtain direct feedback from customers. The firm also works closely with their suppliers in the designing and developing of new products, besides making joint decisions on the pricing, cost and availability. Firm D's response to market developments and changes is based on the advice of suppliers, who inform them about new product trends. Since the print market has been declining both globally and locally, the parent company of Firm D in Europe has taken a proactive role in controlling the selection of suppliers. Performance is regularly measured against its budgets and profit statements monthly:

The changes on the supplier side is notified to us by our manufacturing and product development unit of the parent [company]. We are driven by them and told about the changes. The parent company has the global market perspective. There is an element of the local market perspective and we do have an influence there. We listen to our customers. We look where our customers' markets are going and we are able to tailor to that extent. (Parts and Logistics Manager, Firm D)

Firm E predominantly serves large multinational firms who provide market knowledge through their extensive market research. To respond to market changes, the manager interviewed explained:

Automation has to improve. You must have the latest technology.... We can produce all sorts of different products in these lines. That's one of the changes that we did to respond to market change or demand from the market.

Driven by innovation and sustainability, the firm also recently acquired the latest food processing and packaging technology and the relevant equipment to provide their customers with the competitive edge to stay 
ahead. The information on the firm's website also highlights how with flexible manufacturing, they can produce most liquid products and stay competitive.

The market trends for Firm $\mathrm{F}$ are determined by their account executives who regularly communicate with customers. The firm has a network of contacts in the industry to advise the management on changes happening to the raw materials, technology advancement, or purchasing transactions. New products are developed and tested before being introduced into the production lines, based on customer demand. What gives Firm F a competitive edge is its ability to customise products to suit customer needs:

We are driven by the customers. We might give them advice on what they can use to achieve their end.... If you can provide a customer with a solution to their problem very fast, then they are going to be happy. So, you receive more work and receive increased quantities.... It increases your volume which gives you better buying terms with the mills. So, it is pretty much beneficial. (Senior procurement manager, Firm F)

Firm G captures the market trends internally from its employees, and externally from its suppliers, customers and other external organisations. Its ability to detect the declining trend of the mining industry, one of its major customer segments, has strengthened Firm G's ability to generate revenue from its existing business whilst exploring opportunities for new products and markets:

In the example of our minerals market being lower or being heading into a trough or a downturn, what we needed to do is to look at the existing mineral business and try to generate some revenue from the existing mineral business. But the other strategy that was put in place was to look at what they called a 'XXX markets'. So, we were looking for opportunities to apply some of our technology to other areas, like for example, YYY cement.... It has been put into new product development so that we can develop some of our own markets even in a situation when there is a downturn in one of our major areas. (Sourcing manager, Firm G)

Firm $\mathrm{H}$ identifies the social and environmental needs of its clientele and proactively incorporates changes noted from emerging trends into their designs of trains, trams and rail systems. These 
include the consideration of urbanisation and population growth. Firm $\mathrm{H}$ develops customised mobility solutions in the bid to support mass transportation, and to reduce the social problems caused by such trends. Thus, Firm $\mathrm{H}$ is also involved in R\&D on eco-friendly technologies, in response to the increasing public awareness of pollution and energy efficiency:

Our Eco4 is making sure that in all of our technologies, we are efficient in energy, ecology and economy. How we identify market trends is we are basically very much in touch with the government and political figures within the region. And we also keep tabs on the major trends such as urbanisation, population growth, pollution and energy consumption and of course, constantly what we do is the evolution of mobility. So, what we do is we make sure that we are very much in touch with what the regions' needs are and that we tailor our trains and trams and all our products to accompany that and to mould to the infrastructure currently in place. We are very well in tune with the region's needs. We work very closely with our customers to determine what those needs are and then we tailor our products to suit in that respect. (Head of Communications, Firm H)

\subsubsection{Detecting Changes in Supply and Demand}

The ability of firms to keep abreast with demand and supply lies in the mutually beneficial relationships established with their supply chain partners. The responses from the managers interviewed tended to revolve around this aspect and how they have optimised the collaborative relations for business success. This is especially true when the manufacturing industry is facing high volatility, demand fluctuations and unpredictable market trends.

Firm D believes in the frequent communication with suppliers and customers in order to detect market requirements:

We discuss reasonably openly what we are doing, where we are headed in terms of diversifying the company away from automotive. That's a problem for us long-term. They are supplying what we are making. There are some strategies in place there. We share with our customers and suppliers. So, they know the direction the company is going. (Parts and Logistics Manager, Firm D) 
Firm E on the other hand, operates in the dairy industry which is volatile with highly fluctuating export commodity prices:

You only get two weeks' notice from suppliers. Unfortunately, our customers are not flexible in absorbing these kinds of costs. So, the challenge is always to be able to foresee, which is very difficult.... We work very closely with customers. I think we work more closely with customers than our suppliers. We are trying to improve that system. What we do is, we are trying to follow-up with our clients in different directions.... You need to have an operational level where you connect with them on a monthly or weekly basis and make sure that your supply chain is always demand and supply managed properly. I think a lot of businesses fail there. We are practising just-in-time (JIT) manufacturing systems and managing JIT is very difficult. (General Manager, Firm E)

Firm $G$ is able to identify with the changes in their suppliers' and customers' respective industries based on the close relationships established. As a subsidiary of a multinational company, it receives information about the changes in the supplier and customer market from other subsidiaries:

We also keep in touch with a lot of our suppliers and who are also part of that market, and that we get a lot of information from those suppliers about their industry and the other customers in the industry, also the other suppliers to them in the industry. So, in that way we have an unbelievably good network for obtaining information about market trends.... There's also information from within our company that we get from other parts of the world. So, for example, the price for iron ore, the price of gold, the price of zinc and all the copper, all of those commodities are information that tell us about the market changes or we also get a summary and background information from within our organisation. (Sourcing Manager, Firm G).

\subsubsection{Reconfiguring Supply Chain Resources and Strategies}

Another approach to agility is the firm's ability to reconfigure the supply chain resources and strategies. The findings of this study indicated that manufacturers worked closely with their customers and suppliers to structure the inter-organisational strategies, practices and processes into 
collaborative-synchronised processes, and also for restructuring their internal manufacturing activities at the same time. Faced with unexpected events, challenges or situations, these firms have implemented various solutions or strategies to remain competitive. For example, the changes in foreign exchange have led Firm $G$ to reconsider its strategy and supply structure:

Foreign exchange would be an indication of a market change for us. In other words, it would be more difficult for us to make savings, bringing in materials from other countries when the dollar is very low. Because we would have to pay the difference and purchase those items in the currency which might be very high. So, in those cases, for us sourcing locally might be a better option than sourcing from overseas. And the reverse is also true. When the dollar is strong, then we make a lot of savings when we source products and materials from other countries where their currency is weaker. (Sourcing Manager, Firm G)

Operating in the food industry, Firm B currently faces pressure from European customers to implement traceability systems to meet food safety requirements within these markets. The manager highlighted the need to monitor all livestock in the system. At present, European customers expect a moderate level of traceability and animal rights. However, in realising the importance of animal rights throughout the system, the firm has taken steps to influence all its suppliers and producers to voluntarily adopt the animal traceability system individually at their respective places. The firm has also taken actions to proactively plan for possible future market requirements:

The Europeans are putting pressure on us to do this although the European community currently accepts our traceability. But we are aware that this is impending, and we are trying to get producers and our suppliers to consider adopting voluntarily individual animal traceability systems. We are aware of how things can be changed [in future] and we are trying to get our supply chains to adopt systems to make sure that we are proactive rather than reactive. (Supply Chain Coordinator, Frim B)

Firm A identifies the changes in the building industry via a 1-year, 2-year and 5-year timeframe. The firm proactively develops the ability to meet industry changes by examining the government and industry forecast on the numbers and type of constructions as well as the places 
of construction. In doing that, it reconfigures the supply chain by adjusting the capacities of the factories, logistics and warehouses, in addition to relocating warehouses within the proximity of emerging markets:

When the market changes and there is a new housing sub division in another part of Sydney, we change our supply chain a bit. Maybe open another warehouse close to that new housing sub division.... So, we can supply easier to customers. (Group Supply Chain Manager, Firm A)

\subsubsection{Exploiting Knowledge}

It is widely believed that information integration across partner firms supports supply chain operations, thereby enabling appropriate performance improvements (Dubey et al., 2018). Knowledge exploitation can only succeed with the right conditions and partnerships (Yli-Renko, Autio, \& Sapienza, 2001). For example, integrating a manufacturer's production schedule with the procurement plans of its customers or buying firms, can be helpful for the purpose of adapting changes to product specifications. This allows customers to receive timely status updates on the delivery of their orders, so they can plan their marketing activities. Based on this, it seems evident that knowledge shared among firms can increase stability in manufacturing, procurement, sales and distribution within the supply chain. The ability of firms to exploit knowledge requires the effective coordination of information transfer, collaborative communication and supporting technologies among the firms in the supply chain. Consequently, this could enable joint activity development, work processes, and coordinated decision-making.

The manager in Firm D explained the importance of establishing relationships with supply chain partners:

Being able to build relationships is critical. That's probably number one, I think. If you don't have those relationships in place, people don't understand where you are coming from. You also have got to be able to react and reorganise your business to respond. So you need sort of, I suppose, managerial capabilities to be able to redirect people and resources. (Parts and Logistics Manager, Firm D)

Knowledge can also be sourced externally. For example, Firm D obtains knowledge from industry forums to identify new market developments: 
Our sales and product management team actively take part in industry forums where we get direct feedback from our customers who are also in those industry forums. (Parts and Logistics Manager, Firm D)

In the case of Firm B, food industry exhibitions in Europe and China, and other international forums are seen as a source of vital market information. Moreover, the firm maintains regular communications with its distributors and retailers. Currently, Firm B is undertaking various research projects, working together with an Australian university, the Sheep Meat Council of Australia, Livestock Australia as well as the Sheep Cooperative Research Centre, as a strategy to gather information for new markets for lamb products and also for quality assurance. Firm B is targeting other new high-end market segments through its high-quality premium products:

We have a large marketing team and we have distributors and businesses in America and across Australia. We talk directly to our valuable consumers in Europe. So they feed us their information and they get reported and we discuss the process in that context. Also, we collaborate very strongly with the meat industry partners through Meat and livestock of Australia and the Sheep CRC. At the meetings with those organisations, we discuss these issues and consider potential responses there. (Supply Chain Coordinator, Firm B)

Similarly, Firm $\mathrm{C}$ has also developed a strategy to diversify its products to cater to new markets. It received government funding to develop new products which will be suitable in meeting new market trends:

We are currently in the process of creating new markets for ourselves. We also approach the government and there are various government funding streams available for R\&D. They see the value of what we are doing. (Purchasing Manager, Firm C)

As a part of a multi-national corporation, Firm $\mathrm{H}$ acquires market change knowledge from the other subsidiaries:

We learn a lot from the colleagues overseas in Europe, MiddleEast and Asia. We are in-tune with them. Australia is part of AsiaPacific which obviously includes South-East Asia, India, China and Singapore. We work together on finding bids, tenders and we utilise each other's technology and learn from one another. If 
something happens in Europe now, it might happen in Australia in 2 to 3 years' time. So we can lean on our colleagues there to find a solution. We don't have to create it every time from scratch. Because major trends like overpopulation, urbanisation, energy consumption; all these things are common in the industry across the world. These are not new things for Australia. We have been able to leverage all this information and work together to deliver solutions for customers. This is how we respond to market trends by leaning on the information from colleagues, by learning from our history and also by anticipating what will happen in the next five years, ten years, and twenty years. (Head of Communications, Firm $\mathrm{H}$ )

Our findings reveal that the social interactions and network ties formed by these firms give rise to greater knowledge acquisition and exploitation, which in turn can lead to competitive advantage for firms and their supply chains.

\section{Discussion}

This study is an inquiry into the strategies adopted by eight Australian firms in strengthening their supply chain agility in the manufacturing industry. From the interviews conducted, it is observed that one common feature of supply chain agility stood out prominently among the firms. This feature is the firms' respective efforts in cultivating their commitment to respond to market changes as well as the close participation of their supply chain partners. The firms' ability to embrace market challenges was facilitated by the willingness of their customers and their suppliers to firstly, share current market information; secondly, collaborate on innovative new products; and thirdly, jointly determine new market opportunities. This study also establishes that the firms constantly obtain market information from their customers and suppliers to maintain their agility. These firms adopt various mechanisms to facilitate information sharing with others, such as working closely with supply chain partners and developing strategies to be responsive to the market changes. The findings derived from this study, therefore, indicate that supply chain agility is a collaborative effort of all parties involved in the chain. This supports the findings noted in literature where cooperation among firms is an attribute of the supply chain agility (Chen, 2018; Yusuf et al., 2014). 
Strategic directions could be shared between the firms and their suppliers and customers, thereby enabling the firms to reconfigure their resources, as well as to respond to market changes collectively, as a supply chain.

The communication between organisations occurs through meetings, personal visits and joint productions and planning. Studies (Dubey et al., 2018; Yusuf et al., 2014) looking at supply chain agility have shown how firms integrate business processes and share data using advanced information technologies. It was observed in this study that some firms appeared to have access to their supply chain partners' databases, with the use of advanced technologies. Such an integration is viable only through long-term relationships based on trust.

Our results further indicated that some firms maintained close contacts with industry associations. This was one strategy for the firms to identify market changes early; hence their ability to develop new products that fulfilled market needs. Industry bodies are a good source of market information and new knowledge, enabling these firms to respond to market changes in a timely basis.

Another characteristic found to be linked to agility is proactiveness. The managers anticipate future market changes and prepare for these changes. This is relevant for unexpected changes and uncontrollable events, such as natural disasters and regulatory requirements. Additionally, the firms also create plans for impending market changes by predicting demand and supply, based on the information they had received from their customers and suppliers. This finding is consistent with Fayezi et al. (2015), Gligor \& Holcomb (2012a) and Li et al. (2008; 2009) who espoused that supply chain agility comprises proactive and reactive forms.

Another important finding derived from this study is that firms' responses to market changes can be traced to the firm's core competencies. For example, Firms $\mathrm{A}$ and $\mathrm{C}$ introduce new products based on their core technology for new markets, while Firm B acquire other businesses to strengthen its core competencies. In contrast, Firm E upgrade its technology to improve its core competencies to respond to market changes. These findings reflect that the agile strategies revolve around the core competencies of the focal company.

The findings also reveal that firms reconfigure their resources in the supply chain; this also served as the major feature of the supply chain agility (Charles et al., 2010; Li et al., 2008; Yusuf et al., 2014). The firms' efforts in reconfiguring also altered their strategies when responding 
to market changes. It seems that on the one hand, firms reconfigure supply chains through strategies such as market diversification and vertical integration. On the other hand, firms appear to redesign their supply network structures in terms of activities such as geographically distributed suppliers. Both strategies and network design allow for resource reconfiguration. Vertical integration enable firms to have a higher level of control over their supply chains, and appear as a form of entering into strategic partnerships with suppliers or acquiring distribution channels.

The essence of supply chain agility, according to Gligor et al. (2013), is that it is an organisational level capability which allows for flexibility in responding to changing market conditions in a timely manner. The strategies identified in this study demonstrate the capabilities of coordination and integration for embracing market challenges, and for detecting supply and demand changes. Furthermore, these strategies provide the sensing capability. Firms are able to make transformations during market changes through reconfiguring resources and the respective strategies. Our findings also showed that the inter-organisational relationships provided firms access to market information ahead of their competitors. These capabilities are routine-based and involved tacit components. Consequently, the capabilities derived from agile strategies can lead to the competitive advantage of the firms collectively.

Additionally, the findings derived from the current study provide insights which widen the concept of supply chain agility. The findings reveal that firms responded to market challenges through long-term strategies such as new acquisitions, product or market diversification and new product development. These aspects bring a strategic perspective to responsiveness that exploits the opportunities arising in uncertain markets. Therefore, supply chain agility represents an additional aspect of strategic responsiveness in competitive markets.

The findings also emphasise that for firms to be agile, they need to develop the ability to respond to sudden unexpected changes in markets. The managers interviewed stated that having realised the difficulties experienced during the previous periods of sudden changes, they resorted to modifying the supply chain structure to increase flexibility, which maintained continuous and undisrupted operations during the time. Lee (2004) and Li et al. (2009) have previously recognised this aspect of supply chain agility, particularly among those organisations which had responded quickly to the sudden changes in demand and supply. Developing a scale to measure the supply chain 
agility, Li et al. (2009) was able to determine three levels of agility strategic, operational and episodic. Nonetheless, existing studies are mostly confined to operational agility, which is about demand and supply changes. On the other hand, the findings from this study highlight the strategic aspect of agility embraced by the firms in our sample.

\section{Conclusion and Further Research Direction}

In conclusion, we establish that the agile strategies implemented by the eight firms include: embracing market challenges, detecting changes in demand and supply, reconfiguring resources and strategies, and exploiting knowledge. The findings of this study indicate that firms enhanced their competitiveness by implementing these specific strategies. They develop dynamic capabilities through unique interorganisational relationships, which in turn provided the impetus for the supply chain agility.

\subsection{Practical Implications}

The managers whom we interviewed represent the eight firms selected for this study. Based on our findings, it is considered that these firms are performing well in their industries and our findings also verify that agile strategies enable these firms to be competitive in current turbulent markets. Since supply chain agility is regarded as a collective effort, managers should ensure that other firms are also committed towards responding to market changes. An important aspect in that regard is to develop close relationships with other firms because such collaborations can facilitate information sharing in a timely manner.

Since timely information is crucial, it is inevitable for all firms involved to adopt advanced ICT which facilitate the sharing of real time market data. Our findings have also indicated that not all firms had embraced such technologies. The availability of accurate and real time information is necessary for firms to respond to the demand and supply changes, especially if the firms operate in highly volatile consumer markets. Based on this, there is a need for mangers to advocate for advanced systems that are appropriate for streamlining the key partners in the supply chain.

Additionally, such relationships with industry partners are a good source of information indicating the market directions, where new knowledge can be gained about developing new products and accessing 
new markets. Manufacturers can increase their competitiveness through relationships with industry bodies and supply chain partners. The ability to leverage relationships and access information will undoubtedly, support the need to meet market changes, to adopt mechanisms to speed-up information sharing, and to strategically respond to changes by reconfiguring their supply chains.

\subsection{Theoretical Implications}

This study contributes to the literature by providing empirical evidence regarding the strategies which firms used to enable supply chain agility. This study also expands the concept of supply chain agility to cover 'the abilities required for responding to strategic opportunities and sudden market changes' in addition to the operational level application used by previous studies. Accordingly, this study offers insights from the Australian perspective by extending the concept of supply chain agility; hence, it also contributes to the theoretical perspective.

\subsection{Limitations and Further Research}

In this study, eight firms are purposively selected based on their success and reputation in the industry. We recognise this as a limitation, where only high performing firms were selected. A comparison of high and poor performing firms could validate the results of our study. Additionally, with eight case studies, our findings cannot be generalised; nevertheless, they have theoretical transferability to other similar contexts. This study provides an understanding of the strategies used by firms to enhance their supply chain agility and its impact on competitiveness. Future research in this area could employ a large-scale quantitative study so as to provide a good representation of the subsectors in the manufacturing industry.

\section{References}

Aslam, H., Blome, C., Roscoe, S., \& Azhar, T.M. (2018). Dynamic supply chain capabilities: How market sensing, supply chain agility and adaptability affect supply chain ambidexterity. International Journal of Operations $\mathcal{E}$ Production Management, 38(12), 2266-2285. http://dx.doi.org/10.1108/ IJOPM-09-2017-0555

Australian Bureau of Statistics. (2016). 1292.0 - Australian and New Zealand standard industrial classification (ANZSIC), 2006 (revision 1.0). Retrieved from 
http://www.abs.gov.au/AUSSTATS/abs@.nsf/Previousproducts/9148F 27F324E911BCA25711F00146E35?opendocument

Beske, P. (2012). Dynamic capabilities and sustainable supply chain management. International Journal of Physical Distribution \& Logistics Management, 42(4), 372-387. http://dx.doi.org/10.1108/09600031211231344

Blome, C., Schoenherr, T., \& Rexhausen, D. (2013). Antecedents and enablers of supply chain agility and its effect on performance: a dynamic capabilities perspective. International Journal of Production Research, 51(4), 1295-1318. http://dx.doi.org/10.1080/00207543.2012.728011

Bluhm, D.J., Harman, W., Lee, T.W., \& Mitchell, T.R. (2011). Qualitative research in management: A decade of progress. Journal of Management Studies, 48(8), 1866-1891. http:/ /dx.doi.org/10.1111/j.1467-6486.2010.00972.x

Braunscheidel, M.J., \& Suresh, N.C. (2009). The organizational antecedents of a firm's supply chain agility for risk mitigation and response. Journal of Operations Management, 27(2), 119-140. http://dx.doi.org/10.1016/j.jom. 2008.09.006

Bryman, A. (2008). Social research methods. Oxford: Oxford University Press.

Carvalho, H., Azevedo, S.G., \& Cruz-Machado, V. (2012). Agile and resilient approaches to supply chain management: Influence on performance and competitiveness. Logistics Research, 4(1-2), 49-62. http://dx.doi.org/ 10.1007/s12159-012-0064-2

Castro, H., Putnik, G.D., \& Shah, V. (2012). A review of agile and lean manufacturing as issues in selected international and national research and development programs and roadmaps. The Learning Organization, 19(3), 267-289. http://dx.doi.org/10.1108/09696471211220064

Charles, A., Lauras, M., \& Van Wassenhove, L. (2010). A model to define and assess the agility of supply chains: building on humanitarian experience. International Journal of Physical Distribution \& Logistics Management, 40(8/9), 722-741. http://dx.doi.org/10.1108/09600031011079355

Chen, C-J. (2018). Developing a model for supply chain agility and innovativeness to enhance firms' competitive advantage. Management Decision, (November). http://dx.doi.org/10.1108/MD-12-2017-1236

Chiang, C-Y., Kocabasoglu-Hillmer, C., \& Suresh, N. (2012). An empirical investigation of the impact of strategic sourcing and flexibility on firm's supply chain agility. International Journal of Operations \& Production Management, 32(1), 49-78. http://dx.doi.org/10.1108/01443571211195736

Christopher, M. (2000). The agile supply chain: Competing in volatile markets. Industrial Marketing Management, 29(1), 37-44. http://dx.doi.org/10.1016/ S0019-8501(99)00110-8

Christopher, M. (2011). Logistics and supply chain management. Edinburgh Gate: Pearson Education Limited.

Commonwealth Scientific and Industrial Research Organisation. (2011). Sustainable manufacturing initiative: What does sustainable manufacturing mean to Australia? Retrieved from http://www.csiro.au/en/Organisation-Struc- 
ture/Flagships/Future-Manufacturing-Flagship/Australian-SustainableManufacturing-Initiative.aspx

Commonwealth Scientific and Industrial Research Organisation. (2012). What does sustainable manufacturing mean to Australia? A summary of the CSIRO future manufacturing industry engagement workshop. Retrieved from http:// www.csiro.au/ /media/CSIROau/Portals/Publications/Sustainable $\% 20$ Manufacturing\%20Workshop\%20Report\%202012.pdf.

Creswell, J.W. (2014). Research design: Qualitative, quantitative and mixed methods approaches. Thousand Oaks, CA: SAGE Publications Ltd.

Defee, C.C., \& Fugate, B.S. (2010). Changing perspective of capabilities in the dynamic supply chain era. International Journal of Logistics Management, 21(2), 180-206. http://dx.doi.org/10.1108/09574091011071915

Dove, R. (1994). The meaning of life and the meaning of agile. Production Magazine, 106(11), 14-15.

Dove, R. (1996). Agile supply-chain management. Automotive Production, 108(4), 16-17.

Dubey, R., Altay, N., Gunasekaran, A., Blome, C., Papadopoulos, T., \& Childe, S.J. (2018). Supply chain agility, adaptability and alignment: empirical evidence from the Indian auto components industry. International Journal of Operations \& Production Management, 38(1), 129-148. http://dx.doi. org/10.1108/IJOPM-04-2016-0173

Easterby-Smith, M., Lyles, M.A., \& Peteraf, M.A. (2009). Dynamic capabilities: Current debates and future directions. British Journal of Management, 20(s1), S1-S8. http://dx.doi.org/10.1111/j.1467-8551.2008.00609.x

Eisenhardt, K.M., \& Martin, J.A. (2000). Dynamic capabilities: What are they? Strategic Management Journal, 21(10-11), 1105-1121. http://dx.doi. org/10.1002/1097-0266(200010/11)21:10/11\%3C1105::AID-SMJ133\%3E3.0. CO;2-E

Eshlaghy, A. T., Mashayekhi, A. N., Rajabzadeh, A., \& Razavian, M. M. (2010). Applying path analysis method in defining effective factors in organisation agility. International Journal of Production Research, 48(6), 1765-1786. http://dx.doi.org/10.1080/00207540802566410

Fayezi, S., Zutshi, A., \& O'Loughlin, A. (2015). How Australian manufacturing firms perceive and understand the concepts of agility and flexibility in the supply chain. International Journal of Operations \& Production Management, 35(2), 246-281. http://dx.doi.org/10.1108/IJOPM-12-2012-0546

Gioia, D.A., Corley, K.G., \& Hamilton, A.L. (2012). Seeking qualitative rigor in inductive research: Notes on the Gioia methodology. Organizational Research Methods, 16(1), 15-31. http://dx.doi.org/10.1177\%2F10944281124 52151

Gligor, D.M., \& Holcomb, M.C. (2012a). Antecedents and consequences of supply chain agility: Establishing the link to firm performance. Journal of Business Logistics, 33(4), 295-308. http://dx.doi.org/10.1111/jbl.12003 
Gligor, D.M., \& Holcomb, M.C. (2012b). Understanding the role of logistics capabilities in achieving supply chain agility: A systematic literature review. Supply Chain Management: An International Journal, 17(4), 438-453. http://dx.doi.org/10.1108/13598541211246594

Gligor, D.M., Holcomb, M.C., \& Stank, T.P. (2013). A multidisciplinary approach to supply chain agility: Conceptualization and scale development. Journal of Business Logistics, 34(2), 94-108. http://dx.doi.org/10.1111/jbl.12012

Gligor, D.M., Esmark, C.L., \& Holcomb, M.C. (2015). Performance outcomes of supply chain agility: When should you be agile? Journal of Operations Management, 33-34(1), 71-82. http://dx.doi.org/10.1016/j.jom.2014.10.008

Helfat, C.E., \& Peteraf, M.A. (2009). Understanding dynamic capabilities: Progress along a developmental path. Strategic Organization, 7(1), 91-102. http://dx.doi.org/10.1177/1476127008100133

Helfat, C.E., \& Winter, S.G. (2011). Untangling dynamic and operational capabilities: Strategy for the (N) ever-changing world. Strategic Management Journal, 32(11), 1243-1250. http:/ /dx.doi.org/10.1002/smj.955

International Institute for Management Development. (2018). IMD world competitiveness ranking 2018. Retrieved from https://www.imd.org/wcc/ world-competitiveness-center-rankings/world-competitiveness-ranking2018/

Katkalo, V.S., Pitelis, C.N., \& Teece, D.J. (2010). Introduction: On the nature and scope of dynamic capabilities. Industrial and Corporate Change, 19(4), 11751186. http://dx.doi.org/10.1093/icc/dtq026

Khan K.A., \& Pillania, R.K. (2008). Strategic sourcing for supply chain agility and firms' performance: A study of Indian manufacturing sector. Management Decision, 46(10), 1508-1530. http://dx.doi.org/10.1108/002517 40810920010

Kim, M., \& Chai, S. (2017). The impact of supplier innovativeness, information sharing and strategic sourcing on improving supply chain agility: Global supply chain perspective. International Journal of Production Economics, 187(May), 42-52. http:// dx.doi.org/10.1016/j.ijpe.2017.02.007

Kumar, D., \& Ramakrishna, H. (2011). Assessment of supply chain agility using fuzzy logic for a manufacturing organization. IUP Journal of Supply Chain Management, 8(4), 7-15.

Lannin, S. (2018, July 31). Australian manufacturing businesses warned they must innovate or face imminent collapse. ABCNews. Retrieved from https://www.abc.net.au/news/2018-07-30/manufacturing-industry-toldto-innovate-or-perish/10053016

Lee, H.L. (2004). The triple-A supply chain. Harvard Business Review, 82(10), 102112.

Li, X., Chung, C., Goldsby, T.J., \& Holsapple, C.W. (2008). A unified model of supply chain agility: The work-design perspective. The International Journal of Logistics Management, 19(3), 408-435. http://dx.doi.org/10.1108/ 09574090810919224 
Li, X., Goldsby, T.J., \& Holsapple, C.W. (2009). Supply chain agility: Scale development. The International Journal of Logistics Management, 20(3), 408424. http://dx.doi.org/10.1108/09574090911002841

Manufacturers' Monthly. (2019). Australian manufacturing index indicates slight slowdown in manufacturing. Retrieved from http://www.manmonthly.com. $\mathrm{au} /$ australian+performance+manufacturing+index

Nagel, R.N. (1992). 21st century manufacturing enterprise strategy: An industry-led view. Retrieved from https://apps.dtic.mil/dtic/tr/fulltext/u2/a257032. pdf.

Office of the Chief Economist. (2016). Australian industry report 2016: Economic conditions. Retrieved from https://publications.industry.gov.au/publi cations/australianindustryreport2016/assets/Australian-Industry-Report2016-Chapter-2.pdf.

Qrunfleh, S., \& Tarafdar, M. (2013). Lean and agile supply chain strategies and supply chain responsiveness: The role of strategic supplier partnership and postponement. Supply Chain Management: An International Journal, 18(6), 571-582. http://dx.doi.org/10.1108/SCM-01-2013-0015

Rasli, A.M., \& Mohd, W.M.W. (2008). Project performance framework: The role of knowledge management and information technology infrastructure. Asian Journal of Business and Accounting, 1(2), 39-64.

Rimienè, K. (2011). Supply chain agility concept evolution (1990-2010). Economics $\mathcal{E}$ Management, 16, 892-899.

Scutt, D. (2019, January 7). Australia's manufacturing sector just contracted for the first time in two years. Business Insider. Retrieved from https:// www.businessinsider.com.au/australia-manufacturing-pmi-contractiondecember-2019-1

Swafford, P.M., Ghosh, S., \& Murthy, N. (2006). The antecedents of supply chain agility of a firm: Scale development and model testing. Journal of Operations Management, 24(2), 170-188. http:/ / dx.doi.org/10.1016/j.jom.2005.05.002

Swafford, P.M., Ghosh, S., \& Murthy, N. (2008). Achieving supply chain agility through IT integration and flexibility. International Journal of Production Economics, 116(2), 288-297. http://dx.doi.org/10.1016/j.ijpe.2008.09.002

Teece, D.J. (2007). Explicating dynamic capabilities: The nature and microfoundations of (sustainable) enterprise performance. Strategic Management Journal, 28(13), 1319-1350. http:// dx.doi.org/10.1002/smj.640

Teece, D.J., Pisano, G., \& Shuen, A. (1997). Dynamic capabilities and strategic management. Strategic Management Journal, 18(7), 509-533. http://dx.doi. org/10.1002/(SICI)1097-0266(199708)18:7\%3C509::AID-SMJ882\%3E3.0.CO; $2-Z$

The Australian Industry Group. (2018). Performance indices. Retrieved from https://www.aigroup.com.au/policy-and-research/economics/economic indicators/

Tse, Y.K., Zhang, M., Akhtar, P., \& MacBryde, J. (2016). Embracing supply chain agility: An investigation in the electronics industry. Supply Chain 
Management: An International Journal, 21(1), 140-156. http://dx.doi.org/ 10.1108/SCM-06-2015-0237

Tseng, Y-H., \& Lin, C-T. (2011). Enhancing enterprise agility by deploying agile drivers, capabilities and providers. Information Sciences, 181(17), 3693-3708. http://dx.doi.org/10.1016/j.ins.2011.04.034

van Hoek, R.I., Harrison, A., \& Christopher, M. (2001). Measuring agile capabilities in the supply chain. International Journal of Operations $\mathcal{E}$ Production Management, 21(1/2), 126-148. http://dx.doi.org/10.1108/0144 3570110358495

Van Oosterhout, M., Waarts, E., \& van Hillegersberg, J. (2006). Change factors requiring agility and implications for IT. European Journal of Information Systems, 15(2), 132-145. http:/ / dx.doi.org/10.1057/palgrave.ejis.3000601

Vázquez-Bustelo, D., Avella, L., \& Fernández, E. (2007). Agility drivers, enablers and outcomes: Empirical test of an integrated agile manufacturing model. International Journal of Operations \& Production Management, 27(12), 13031332. http://dx.doi.org/10.1108/01443570710835633

Wang, C.L., \& Ahmed, P.K. (2007). Dynamic capabilities: A review and research agenda. International Journal of Management Reviews, 9(1), 31-51. http:// dx.doi.org/10.1111/j.1468-2370.2007.00201.x

Wieland, A. (2013). Selecting the right supply chain based on risks. Journal of Manufacturing Technology Management, 24(5), 652-668. http://dx.doi.org/ 10.1108/17410381311327954

Wu, K-J., Tseng, M-L., Chiu, A.S.F, \& Lim, M.K. (2017). Achieving competitive advantage through supply chain agility under uncertainty: A novel multi-criteria decision-making structure. International Journal of Production Economics, 190(August), 96-107. http://dx.doi.org/10.1016/j. ijpe.2016.08.027

Yang, J. (2014). Supply chain agility: Securing performance for Chinese manufacturers. International Journal of Production Economics, 150(April), 104-113. http://dx.doi.org/10.1016/j.ijpe.2013.12.018

Yin, R.K. (2018). Case study research and applications: Design and methods. Thousand Oaks, CA: Sage.

Yli-Renko, H., Autio, E., \& Sapienza, H.J. (2001). Social capital, knowledge acquisition, and knowledge exploitation in young technology-based firms. Strategic Management Journal, 22(6-7), 587-613. http://dx.doi.org/10.1002/ smj.183

Yusuf, Y.Y., Gunasekaran, A., Musa, A., Dauda, M., El-Berishy, N.M., \& Cang, S. (2014). A relational study of supply chain agility, competitiveness and business performance in the oil and gas industry. International Journal of Production Economics, 147(Part B), 531-543. http://dx.doi.org/10.1016/j. ijpe.2012.10.009 


\section{Appendix: The Interviewee's Profiles}

\begin{tabular}{ll}
\hline Firm & Interviewee profile \\
\hline Firm A & Group Supply Chain Manager \\
Firm B & Supply Chain Coordinator \\
Firm C & Purchasing Manager \\
Firm D & Parts and Logistics Manager \\
Firm E & General Manager \\
Firm F & Senior Procurement Manager \\
Firm G & Sourcing Manager \\
Firm H & Head of Communications \\
\hline
\end{tabular}


